\title{
Effect of strategic gastrointestinal nematode control on faecal egg count in traditional West African cattle
}

\author{
Jakob ZINSSTAG ${ }^{\text {a* }}$, Philippe ANKers ${ }^{\mathrm{b}}$, Mamud NJIE ${ }^{\mathrm{c}}$, Pradeep ITTY ${ }^{\mathrm{d}}$, \\ Vincent MONSAN ${ }^{\mathrm{e}}$, Johannes KAUFMANN ${ }^{\mathrm{f}}$, Tom SMITH ${ }^{\mathrm{a}}$, \\ Vijay S. PANDEYg ${ }^{\mathrm{g}}$ Kurt PFISTER ${ }^{\mathrm{h}}$ \\ a Swiss Tropical Institute, PO Box, 4002 Basle, Switzerland \\ ${ }^{\mathrm{b}}$ Rue des Riettes, 1145 Bière, Switzerland \\ ${ }^{c}$ International Trypanotolerance Centre, P.M.B. 14, Banjul, The Gambia \\ ${ }^{d}$ Swiss Centre for International Agriculture (ZIL), ETH, 8092 Zürich, Switzerland \\ e UFR Mathématiques et Informatiques, Université de Cocody, 22 BP 582, \\ Abidjan 22, Ivory Coast \\ ${ }^{\mathrm{f}}$ Swiss Embassy, 2900 Cathedral Ave. NW, Washington DC 20008-3499, USA \\ g Prince Leopold Institute of Tropical Medicine, Nationalestraat 155, 2000 Antwerp, Belgium \\ ${ }^{\mathrm{h}}$ Department of Zoology, University of Neuchâtel, rue E. Argand 11, \\ 2000 Neuchâtel, Switzerland
}

(Received 20 May 1999; accepted 10 December 1999)

\begin{abstract}
This paper reports on the effect of strategic anthelmintic treatments and other determinants on faecal egg counts (FEC) of Trichostrongyles in N'Dama cattle of a west African village. Initially, 527 animals from 13 private N'Dama cattle herds were monitored in a longitudinal study from October 1989 to December 1994. Each herd was stratified by age and animals were sequentially allocated to two groups with similar age distributions. One group received a single anthelmintic treatment of fenbendazole $(7.5 \mathrm{mg} / \mathrm{kg} \mathrm{BW})$, in October $1989(\mathrm{n}=250)$, whereas the other group remained untreated $(n=277)$ throughout the study. In the next rainy season (June to October), the treated animals were treated twice (in July and September). The same treatment schedule was used in the subsequent rainy seasons until December 1994. Biannual anthelmintic treatments decreased the level of FEC between $31 \%$ (late dry season) and 57\% (rainy season), when compared to untreated controls. The highest levels of FEC were found during the rainy season from June to October. FEC levels decreased until 4 years of age, after which they remained on a constant low level. The variability of returns to anthelmintic treatments between herds did not seem to be influenced by FEC at the herd level. The financial evaluation of anthelmintic interventions cannot be predicted from FEC and must necessarily rely on the direct monitoring of livestock productivity parameters.
\end{abstract}

gastrointestinal nematodes / N'Dama cattle / faecal egg count / strategic control / fenbendazole

* Correspondence and reprints

Tel. : (41) 6128481 39; fax: (41) 6127179 51; email: Jakob.Zinsstag@ unibas.ch 
Résumé - Effet d'une vermifugation ciblée sur le niveau d'excrétion des oufs dans les fèces de bovins en Afrique de l'Ouest. Ce travail présente l'effet de traitements anthelmintiques ciblés et d'autres déterminants sur l'excrétion des œufs de strongles gastro-intestinaux dans les fèces de bovins N'Dama en Afrique de l'Ouest. Initialement 527 animaux dans 13 troupeaux villageois ont été suivis de octobre 1989 à décembre 1994. Les troupeaux ont été stratifiés par age et subdivisés en deux groupes traitements. Un groupe $(\mathrm{n}=250)$ a été vermifugé avec du fenbendazole $\left(7.5 \mathrm{mg} \cdot \mathrm{kg}^{-1} \mathrm{de}\right.$ poids corporel) en octobre 1989 tandis que l'autre groupe $(n=277)$ est resté sans traitement pendant tout le temps de l'étude. Au cours de la saison des pluies suivante (de juin à octobre), les animaux déjà traités ont reçu 2 vermifugations (en juillet et en septembre). Le même calendrier de traitement a été utilisé au cours des saisons des pluies suivantes jusqu'en décembre 1994. Un traitement bisannuel diminuait le niveau de l'excrétion des œufs dans les fèces de $31 \%$ (fin de saison sèche) à $57 \%$ (saison des pluies) comparé au groupe témoin. Les niveaux les plus élevés de l'excrétion des œufs dans les fèces ont été trouvés en saison des pluies de juin à octobre. Le niveau de l'excrétion des œufs dans les fèces diminuait jusqu'à l'âge de quatre ans et restait constant à un niveau bas par la suite. La variation de la rentabilité d'une vermifugation bi-annuelle entre troupeaux ne semble pas être liée au niveau de l'excrétion des œufs dans les fèces du troupeau. La rentabilité d'une intervention anthelmintique ne peut être prédite à partir du niveau d'excrétion des œufs dans les fèces et doit nécessairement être estimée directement à partir des paramètres de productivité.

nématodes gastrointestinaux / bovins N'Dama / coprologie / vermifugation ciblée / fenbendazole

\section{INTRODUCTION}

Trypanotolerant N'Dama cattle, about $6 \%$ of the bovine population of Africa [17], play an important role in the agricultural economy of tsetse affected areas in west and central Africa [2]. Through further genetic improvement [12], and improved nutrition [4], N'Dama cattle may contribute even more to sustainable livestock production in situations with low to medium trypanosome prevalence [7]. Because the major contagious diseases are more or less under control in this part of Africa, gastrointestinal nematodes [6] and other parasites [3] remain one of the major constraints to the health of trypanotolerant livestock.

Kaufmann et al. [10] demonstrated a strong pathologic synergism between Trypanosoma congolense and Haemonchus spp. in N'Dama cattle, which emphasises the importance of gastrointestinal nematode control for the maintenance of trypanotolerance in this breed. The prevalence of gastrointestinal nematodes Haemonchus spp., Trichostrongylus spp., Cooperia spp., Oesophagostomum radiatum and Bunostomum phlebotomum in west African cattle is close to $100 \%$ [9, 14-16]. Over $80 \%$ of the nematode burden in Gambian N'Dama cattle occurs during the rainy season [9].

A large-scale, randomised intervention field study showed that two annual fenbendazole $\left(7.5 \mathrm{mg} \cdot \mathrm{kg}^{-1} \mathrm{BW}\right)$ treatments increase liveweights of one to four year old animals between 8 and $17 \%$ [24], reduce age at first calving by 8 months $(25 \%$ of age at first calving) and increase calving rates by $8 \%$, but do not influence mortality [25]. These results and financial data on treatment costs were used in a herd simulation model to assess the profitability of the intervention by the method of Itty et al. [8]. The bioeconomic herd model used simulates whole herd productivity, derived from averaged observational data, over a ten year period, including discounting. It includes demographic herd composition, mortality, calving rates, age at first calving, milk production and offtake rates with and without the intervention. Monetary values of the herd productivity with and without anthelmintic interventions are determined at the end of the ten year simulation period to calculate benefit-cost ratios. Two annual anthelmintic treatments were profitable on the average 
(Benefit-cost ratio $=1.14)$ but highly variable between herds. The treatment scheme can only be recommended in certain herds and further research is needed to identify the factors determining the large between herd variation of returns [8]. One reason for the variability of returns to anthelmintic treatment might be the variation of nematode burden on the herd level.

In this paper, we present the effect of strategic anthelmintic treatments on Trichostrongyle faecal egg counts (FEC) in the above study $[8,24,25]$ together with important determinants of FEC, such as age and season.

\section{MATERIALS AND METHODS}

\subsection{Animals and treatments}

The study was conducted in the Central River Division in The Gambia which has a savannah woodland type vegetation [24]. The rainy season extends from June to October with a mean annual rainfall of 600-1200 mm. Animals are managed under a traditional extensive village system and are grazed on natural communal pastures throughout the year. During the rainy season, animals are attached with individual ropes to pegs on night holding places for up to 16 hours a day. Grazing is short to avoid damage to the growing crop (millet, groundnut, maize) and animals are led into the communal bush (derived savannah). There are no artificial pastures. Cattle herds are driven by herdsmen and are well supervised. Communal land is not fenced and effects of accumulation are negligible in comparison to the night holding places [11]. In the dry season, animals are held on harvested crop fields to fertilise them. Nematode transmission is negligible on communal pasture in the dry season [23]. Some herds migrate during the dry season to swampy areas on the shore of the river Gambia, where they find green grass also in the dry season. Animals are generally watered from wells except for some herds, which are close to the river or close to naturally formed ponds in the rainy season.

Initially, 527 animals from 13 private N'Dama cattle herds were monitored in a longitudinal study from October 1989 to December 1994.

Herd selection criteria for this study were: willingness to participate and location within the study area of the Central River Division. The final analysis was carried out on 10 herds (drop-out risk 23\%). Each herd was stratified by age and animals were sequentially allocated to two groups with a similar age distribution. One group received a single anthelmintic treatment of fenbendazole (Panacur ${ }^{\mathrm{TM}} 7.5 \mathrm{mg} \cdot \mathrm{kg}^{-1} \mathrm{BW}$, Hoechst Veterinär $\mathrm{GmbH}$, Germany) in October 1989 $(n=250)$, whereas the other group remained untreated $(n=277)$ throughout the study. During the next rainy season (June to October), the treated animals were treated again twice (in July and September). The same treatment schedule was used in the subsequent rainy seasons until December 1994, to measure effects of repeated annual treatments on the same animals. Animals purchased during the observation period were allocated to the control group to avoid a dilution of cumulative treatment effects.

Besides the recording of productivity and demographic parameters as presented by Zinsstag et al. [24, 25], every three months, all animals were checked for gastrointestinal helminth egg excretion $(\mathrm{EPG}=$ eggs per gram faeces) using the McMaster technique (360 $\mathrm{g} \mathrm{NaCl} \cdot \mathrm{L}^{-1}$, specific density 1.20$)$ [1].

\subsection{Data preparation and analysis}

The lower limit of detection of faecal eggs was 100 EPG. Because almost all animals harbour gastrointestinal nematodes [9, 14] and the sensitivity of the McMaster technique is poor, the analyses focused on the identification of the effect of strategic 
anthelmintic treatments (in July and September) and on the most important determinants of FEC levels. The FEC data were sorted by individual animals in the order of the sampling sequence. For animals having missing values, only the longest uninterrupted sequence of samples was analysed. The final data set contained $n=6656$ samples, from 817 animals. The number of samples per animal ranged from 2 to 20, with a mean of 8.1 (standard deviation: 5.4). Distributions are generally highly skewed, containing at the same time very high counts and substantial numbers of samples with zero or undetectable levels of infection [18]. This makes it inappropriate to analyse them using normal models [22]. Generalized estimating equations (GEE) extend multivariate analysis relaying on normally distributed residuals to a family of exponential distributions such as binomial and Poisson distributions.

In this study, the Poisson models, scaled to allow for overdispersion [20], with a log link function and an autoregressive correlation structure to account for the independence between repeated samples on the same animal, were used to test simultaneous contributions of the variables listed in Table I to the FEC. The models were fitted using the SAS PC Version 6.12 (SAS Institute Inc., Cary, USA), using GEE [13].

\section{RESULTS}

The parasite spectrum observed in the coprological analysis comprised Trichostrongyles $(n=9311)$. The overall prevalence of Trichostrongyle faecal eggs was 32 in the treated animals $(n=4187)$ and $47 \%$ in the untreated control animals $(\mathrm{n}=5124)$. Strongyloides papillosus, Monezia sp. and Toxocara vitulorum had all less than $1 \%$ prevalences. Strongyloides papillosus eggs were found only in suckling calves under one year of age. The frequency distribution of the Trichostrongyle FEC is skewed in the typical way (data not shown)
Table I. Likelihood ratio statistics for the Poisson model analysing the statistical significance of explanatory variables for the level of faecal egg counts.

\begin{tabular}{lcc}
\hline $\begin{array}{l}\text { Explanatory } \\
\text { variable }\end{array}$ & $\begin{array}{c}\text { Degrees of } \\
\text { freedom }\end{array}$ & $\begin{array}{c}\text { Chi Square } \\
\text { (all p }<0.001)\end{array}$ \\
\hline Season & 3 & 978.0 \\
Year & 4 & 60.3 \\
Herd & 9 & 127.5 \\
Age & 3 & 929.3 \\
Treatment & 1 & 299.0 \\
Treatment* Herd & 9 & 63.9 \\
Treatment* Season & 3 & 18.8 \\
Treatment* Year & 4 & 19.1 \\
\hline
\end{tabular}

Seasons were: early dry season (November to March); late dry season (April to June); early rainy season (July to August); and the late rainy season (September to October). Age in years was modelled as a third degree polynomial. ${ }^{*}$ indicates first order interactions.

and the majority of the animals were low egg excreters (0-200 EPG).

Table I shows the likelihood ratio statistics for the GEE models. The terms included accounted for $30 \%$ of the total deviance. The distribution of FEC was moderately overdispersed (scale parameter $=1.8$ ). The effect of treatment was highly significant as well as its interactions with herd, season and year. Parameter estimates generated from the GEE model were used to estimate treatment effects in different seasons. In the late dry season the fitted values of FEC for controls were 166 (95\% Confidence Interval (CI): 141-195) and 113 (95\% CI: 91-141) for treated animals, corresponding to a $31 \%$ reduction. In the rainy season the fitted values of FEC for controls were 314 (95\% CI: 271-364) and 133 (95\% CI: 108-166) for treated animals, corresponding to a $57 \%$ reduction, with a prolonged effect into the next early dry season. Seasonal variation influenced very significantly the level of FEC, with lowest levels in the early dry 
season. FEC rose already in the late dry season and peaked during the early rainy season (July to August) (Fig. 1). Annual variations are much less significant and annual cumulated rainfall did not correlate with FEC (data not shown). Variation between herds exerted a significant effect on FEC, as well as the age of the animals.

Plots of geometric mean FEC values (Fig. 1) confirm the distinct seasonal pattern of Table I, with peaks (range 30-70 epg) occurring in the rainy season between June and October. Because of the skewness in the FEC distribution, geometric means were much lower than arithmetic means, for example most animals were not excreting eggs or were sub-patent. During the dry season from November to May, geometric mean FEC dropped to values of <10 epg. The decrease of the geometric mean FEC in the treated group was highest during the rainy season. Figure 2 shows the observed geometric mean FEC related to age in years. In the control group, FEC was the highest in young animals, decreased up to 4 years and increased slightly in older animals.

\section{DISCUSSION}

Two annual strategic treatments during the peak of gastrointestinal nematode excretion were sufficient to reduce contamination with Trichostrongyle eggs by $31-57 \%$. They are related to an average benefit-cost ratio of 1.14 for the intervention (implying borderline profitability) [8]. The estimates obtained from the GEE model confirmed the trends observed in overall descriptive plots in Figure 1. The observed decreased of FEC with age (Fig. 2), in line with Fall et al. [4], is probably related to the acquisition of immunity. This acquisition, expressed as a decrease of FEC values in older animals, appears to take longer in N'Dama cattle than described with other breeds in different climatic conditions [5, 19]. Seasonal malnutrition most likely affects the age dependence of FEC [24], which reach a minimum

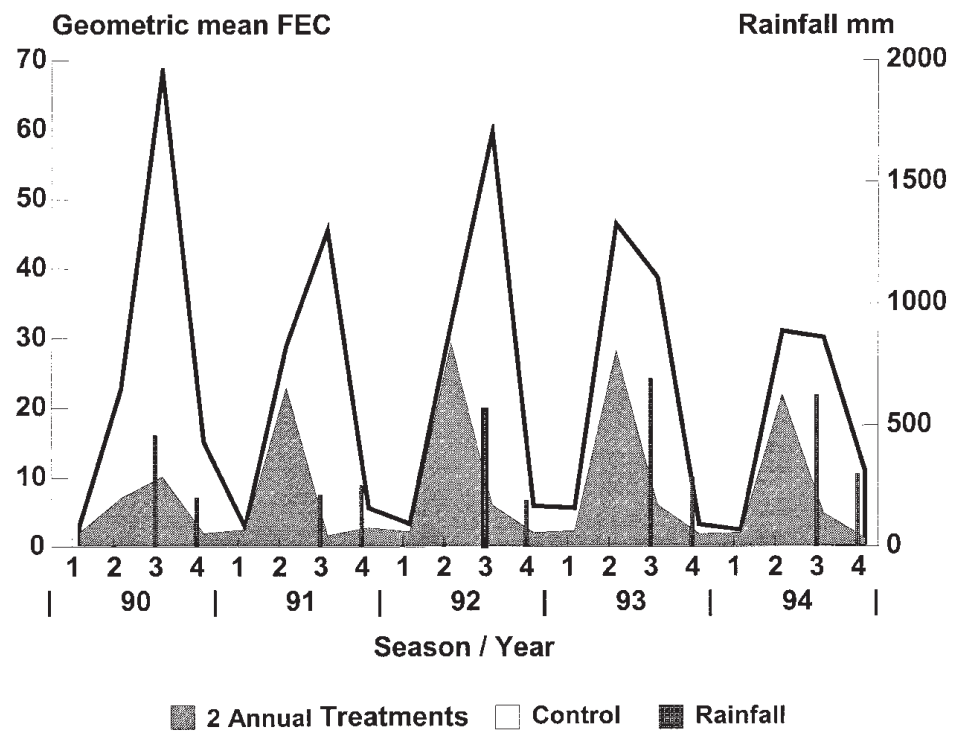

Figure 1. Rainfall and geometric mean faecal egg count by season and year. Seasons: $1=$ November to March (early dry); 2 = April to June (late dry); 3 = July and August (early wet); 4 = September and October (late wet). 


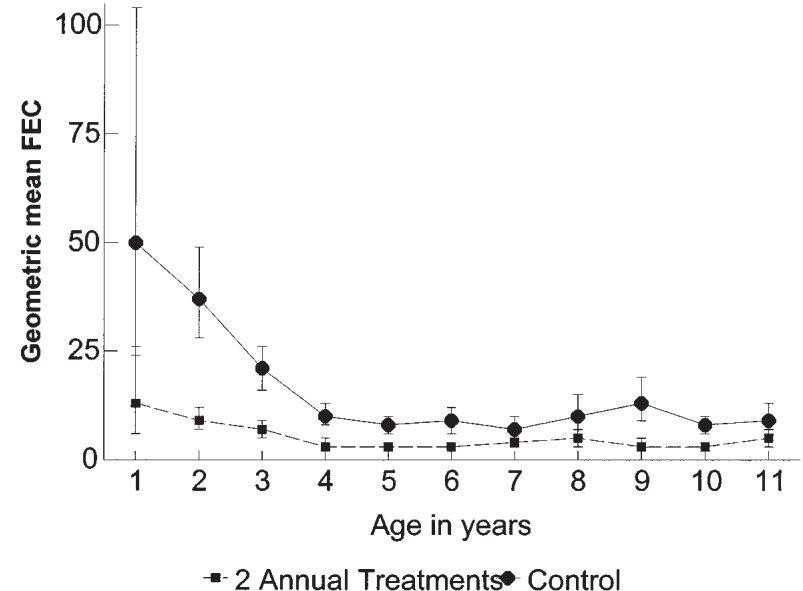

Figure 2. Age dependence of observed geometric mean faecal egg count by treatment group (error bars indicate $95 \%$ confidence intervals). only after the age of five years. This is reflected in the effects of the control scheme on growth of the same animals, which is significantly improved between one and four years of age [24].

Since animals were sampled only every three months, anthelmintic efficacy (using a standard 10 day test for FEC decrease) could not be assessed. In contrast to the general pattern described by Hörchner [6], Toxocara vitulorum is not important in The Gambia [9] and the Casamance region, Senegal [4]. Two treatments in the rainy season reduce the seasonal peak considerably, despite rapid reinfection after the first treatment in July. Reinfection remains on a low level after the treatment in September which coincides with the onset of hypobiosis [24]. Thereby a certain natural exposure to the parasite remains which is necessary to build up immunity. Fasciola gigantica is present in The Gambia (J. Zinsstag, unpublished data) on a relatively low scale, focalised in areas with seasonal swamps or close to the river. Additional treatment for trematodes was not considered necessary and was never done for individual animals in the experimental herds.

Identification and treatment of heavily infected animals could considerably decrease pasture contamination and the risk of infection, but we were not able to assess the feasibility, or economic benefits of such a strategy. In the field, most farmers deworm only a few of their animals, but do not select them on the basis of parasitological diagnoses. Hence, untreated animals remain in the same herd and provide important reservoirs for reinfection. This was intentionally adopted in our study to maintain a certain challenge in every herd for the build up of acquired immunity.

Productivity parameters published by Zinsstag et al. [24, 25], and parasitological results between treatment groups were compared on individual and herd levels. For this, liveweight and calving rates were regressed on predicted FEC levels. In the same way, profitability of deworming, expressed as the benefit-cost ratio from Itty et al. [8] were correlated with the Poisson predicted FEC. Although the treatment had highly significant effects on both FEC and productivity measures [24, 25], the herd level FECs were not significantly correlated with herd level productivity measures such as calving rates and body weights (data not shown). Herd level benefit-cost ratios of two annual anthelmintic treatments derived from the economic analysis by Itty et al. [8] in the same study, showed no significant relationship with FECs of the same herds (data not 
shown). The estimated returns of two annual anthelmintic treatments, as presented by Itty et al. [8], for this study are on the average 1.14 (benefit-cost ratio), but showed high standard errors, reflecting differences of treatment effects between herds [8]. Financial returns at the herd level were not closely related to the parasitological impact and are in line with the findings of Smith and Galligan [21]. This analysis only had limited power because of the low number of herds studied, but it seems likely that the large variations in the profitability of treatment had causes other than variations in the initial levels of infection of the herds. Further research is needed to identify the factors determining the large between herd variation of returns to strategic anthelmintic treatment.

We conclude that in the present context of traditional livestock systems in The Gambia, two annual anthelmintic treatments (July and September) decrease faecal egg counts between $31 \%$ and $57 \%$.

\section{ACKNOWLEDGMENTS}

This study was sponsored by the Swiss Development Cooperation. We acknowledge the participating farmers, the directors Prof. L. Dempfle and Dr. Bakary Touray and the staff of the International Trypanotolerance Centre. We are very grateful for the excellent technical assistance of the project staff.

\section{REFERENCES}

[1] Boch J., Supperer R., Eckert J., Kutzer E., Rommel M., Veterinärmedizinische Parasitologie, Berlin, Verlag Paul Parey, 1983, 533 p.

[2] d'Ieteren G.D., Authie E., Wissocq N., Murray M., Trypanotolerance, an option for sustainable livestock production in areas at risk for trypanosomosis, Rev. Sci. Tech. OIE 17 (1998) 154175 .

[3] Dorchies P., Multiparasitism in sub-Saharan West African countries: don't forget the least important! Parasitol. Today 14 (1998) 468.

[4] Fall A., Diack A., Diaité A., Seye M., d'Ieteren G.D.M., Tsetse challenge, trypanosome and helminth infection in relation to productivity of village Ndama cattle in Senegal, Vet. Parasitol. 81 (1999) 235-247.

[5] Gronvold J., Nansen P., Gasbarre L.C., Christensen C.M., Larsen M., Monrad J., Midtgaard N., Development of immunity to Ostertagia ostertagi (Trichostrongylidae: Nematoda) in pastured young cattle, Acta Vet. Scand. 33 (1992) 305-316.

[6] Hörchner F., Proposals for epidemiological surveys of helminthoses aimed at the improvement of livestock production in the tropics, Trop. Med. Parasitol. 41 (1990) 422-424.

[7 ] Itty P., Economics of village cattle production in tsetse affected areas of Africa: a study of trypanosomiasis control using trypanotolerant cattle and chemotherapy in Ethiopia, Kenya, Cote d'Ivoire, The Gambia, Zaïre and Togo, HartungGorre Verlag Konstanz, 1992, 316 p.

[8] Itty P., Zinsstag J., Ankers P., Njie M., Pfister K., Returns from strategic anthelmintic treatments in village cattle in the Gambia, Prev. Vet. Med. 32 (1997) 299-310.

[9] Kaufmann J., Pfister K., The seasonal epidemiology of gastrointestinal nematodes in N'Dama cattle in The Gambia, Vet. Parasitol. 37 (1990) 45-54.

[10] Kaufmann J., Dwinger R.H., Hallebeek A., van Dijk B., Pfister K., The interaction of Trypanosoma congolense and Haemonchus contortus infections in trypanotolerant N'Dama cattle, Vet. Parasitol. 43 (1992) 157-170.

[11] Kaufmann J., Komma A., Pfister K., Effect of herd management on the contamination of night holding areas (correos) and infections with gastrointestinal nematodes of N'Dama cattle in The Gambia, Trop. Anim. Health. Prod. 27 (1995) 76-82.

[12] Kemp S.J., Teale A.J., Genetic Basis of Trypanotolerance in Cattle and Mice, Parasitol. Today 14 (1998) 450-454

[13] Liang K.-Y., Zeger S.L., Longitudinal data analysis using generalized linear models, Biometrika 73 (1986) 13-22.

[14] Ndao M., Belot J., Zinsstag J., Pfister K, Épidémiologie des nématodes gastro-intestinaux des ruminants dans la zone sylvo-pastorale au Sénégal, Vet. Res. 26 (1995) 132-139.

[15 ] Ndao M., Pandey V.S., Zinsstag J., Pfister K., Helminth parasites and hypobiosis of nematodes in N'dama cattle during the dry season in the Gambia, Vet. Parasitol. 60 (1995) 161-166.

[16] Ouattara L., Ouédraogo A., Kaufmann J., Pfister, K. Épidémiologie des nématodes gastrointestinaux des ruminants au Burkina Faso, in: Proceedings of the VII International Conference of Institutions ot Tropical Veterinary Medicine (AITVM), Yamoussoukro, Côte d'Ivoire, Deutsche Stiftung für Internationale Entwicklung 2 (1992) 497-505. 
[17] Paling R.W., Dwinger R.H., Potential of trypanotolerance as a contribution to sustainable livestock production in tsetse affected Africa, Vet. Q. 15 (1993) 6067.

[18] Pandey V.S., Host-parasite relationship: its implications in epidemiology and control of helminth infections of livestock, Helminthologia 32 (1995) 151-160.

[19] Ploeger H.W., Kloosterman A., Borgsteede F.H., Eysker M., Effect of naturally occurring nematode infections in the first and second grazing season on the growth performance of second-year cattle, Vet. Parasitol. 36 (1990) 57-70.

[20] SAS Institute Inc., SAS/STAT Software: Changes and enhancements through Release 6.11, Cary, NC, SAS Institute Inc., 1996, 1104 p.

21] Smith G., Galligan D.T., Mathematical models of the population biology of Ostertagia ostertagi and Teladorsagia circumcincta, and the economic evaluation of disease control strategies, Vet. Parasitol. 27 (1988) 73-83.

[22] Smothers C.D., Sun F., Dayton A.D., Comparison of arithmetic and geometric means as measures of a central tendency in cattle nematode populations, Vet. Parasitol. 81 (1999) 211-224.

[23] Zinsstag J., Njie M., Kaufmann., Pfister K., Prolonged suppression of trichostrongyle egg output of N'Dama cattle by a single larvicidal treatment, Acta Tropica 58 (1994) 99-103.

[24] Zinsstag J., Ankers P., Dempfle L., Njie M., Kaufmann J., Itty P., Pfister K., Pandey V.S., Effect of strategic gastrointestinal nematode control on growth of N'Dama cattle in Gambia, Vet. Parasitol. 68 (1997) 143-153.

[25] Zinsstag J., Ankers P., Itty P., Njie M., Kaufmann J., Pandey V.S., Pfister K., Effect of strategic gastrointestinal nematode control on fertility and mortality of N'Dama cattle (The Gambia), Vet. Parasitol. 73 (1997) 105-117. 